\title{
Spawning sounds in meagre Argyrosomus regius recorded in the Gironde estuary, France
}

\author{
J.P. Lagardère* $†$ and A. Mariani§ \\ * CNRS-Ifremer, Centre de recherche sur les Ecosystèmes marins et Aquacoles, BP 5, 17137 \\ L'Houmeau - France \\ $\S$ CNRS, Centre d'Etudes Biologiques de Chizé, 79360 Villiers-en-Bois, France \\ †: Corresponding author : Tel.: 335580417 72; fax: 335465006 00; email: jplagard@free.fr \\ or jplagard@ifremer.fr
}

\begin{abstract}
:
During their spawning period (June to mid-July) in the Gironde estuary, meagre Argyrosomus regius produce two distinct sounds: regular long grunts, the most common calls, and sometimes also short grunts. It is suggested that long grunts serve the formation of spawning aggregations and short grunts announce the beginning of courtship behaviour. The meagre's long grunts include long series of 30112 closely spaced pulses placed into call units. Each pulse produces multiple and rapidly decaying swimbladder vibrations with a dominant frequency varying between 336 and $444 \mathrm{~Hz}$.
\end{abstract}

Keywords: sound production, meagre, fish, spawning period, sonic muscle 


\section{INTRODUCTION}

The Sciaenidae is among the largest families of sonic fishes, comprising some 150 species within 30 genera (Ono \& Poss, 1982; Chao, 1986). The meagre, Argyrosomus regius (Asso, 1801), is a sciaenid widely distributed along the Atlantic coast (northward to southern Norway and southward to the Congo) including the whole Mediterranean (Chao, 1986). This fish has been known for centuries to produce sounds (Duhamel de Monceau, 1777; Dufossé, 1874). In the Gironde estuary, this long-standing knowledge by fisherfolk is associated with fishing of this species during spawning period. During the spawning season (May to July), large choral aggregations of male and female meagre form, and their mating calls facilitate fishing in this particular spawning site (Duhamel de Monceau, 1777; Quéro, 1989a). Fishermen listen, with their ear to the hull of theirs boats, to the aggregative calls and try to place their gillnets as close as possible to the fish aggregations.

Typically male sciaenids possess the ability to produce species-specific drumming sounds during their courtship of females at spawning locations (Fish \& Mowbray, 1970; Mok \& Gilmore, 1983; Connaughton \& Taylor, 1995; Connaughton \& Taylor, 1996; Luczkovich et al., 1999). However, meagre as well as two Japanese marine drum fishes, Nibea albiflora and Argyrosomus argentatus (Takemura et al., 1978), theAtlantic croaker (Micropogon undulatus L.), and the black drum Pogonias cromis (Fish \& Mowbray, 1970; M. Fine, pers. com.) are exceptions in that both males and females possess the extrinsic sonic muscles common to the family (Dufossé, 1874; Hill et al., 1987) and both sexes could produce sounds.

Hydrophone tape recordings of vocalizations produced by meagre were carried out during several fishing cruises in the Gironde estuary. The aim of this study was to describe, for the first time, the specific spawning sound types produced by meagre through sonographic analyses.

\section{MATERIALS AND METHODS}

This study was carried out during the reproductive season for meagre, in June and July 2003 and 2004. The recording material was taken aboard a Gironde estuary fishing boat, and the recordings were made either during the drifting of the boat pulling the net, with the engine stopped, or during periods when the fisherman was listening for fish aggregations. The best recordings were during slack tide in the late afternoon when the currents cancelled each other out and their "blowing effect" on the hydrophone stopped. Water temperature was between 16 and $21^{\circ} \mathrm{C}$ and turbity was very high (Irigoien \& Castel, 1997; Doxaran et al., 2002; Schäfer et al., 2002).

Sounds were recorded with an omnidirectional hydrophone HTI 16400 (HTI Inc., USA) with a built-in preamplifier connected to a portable DAT recorder (Sony TCD-D8). They were then analysed using a Tektronix 2622 FFT analyser and IP software (1024-point Hanning windowed FFT) providing oscillograms and averaged frequency spectra. Sonographic analysis of the signals (previously digitised by a 16-bit acquisition card equipped with an antialiasing filter at a sampling rate of $16 \mathrm{kHz}$ ) was conducted with the SYNTANA analytic package (Aubin, 1994; Lengagne et al., 2000) and, with a filter bandwidth of $100 \mathrm{~Hz}$, wide-band frequency spectra were obtained. The following temporal and spectral characteristics of the sound waves were measured: call or train duration in ms (measured as the time interval between the onset of one train and its end); number of pulses in a train; pulse length in ms; pulse period in ms (measured as the average peak to peak interval between consecutive pulse units in the train); number of peaks in a pulse and dominant frequency (see 
also figure 2). Dominant frequency represents the most intense frequency (in $\mathrm{Hz}$ ) of the individual sound pulses (Connaughton et al., 2000).

\section{RESULTS}

The extrinsic sonic muscles and the swimbladder

In males, the sonic muscles form two broad bands, fringed by a dark red colour and running along the posterior $3 / 4$ of the body cavity in close association with the swimbladder (Fig. 1A and B). These extrinsic sonic muscles are bilaterally symmetrical and are attached with trunk muscles to form the lateral body walls. They encircle the viscera and the swimbladder on the posterior $3 / 4$. The muscles insert on a connective tissue sheet (aponeurosis) that sits on the top of the swimbladder. The sonic muscles were enlarged during the spawning period (Fig. $1 \mathrm{~A}$ and B) in contrast to a male, weighing $17 \mathrm{~kg}$ (1.10 m length), observed in March 2004. Its smaller sonic muscles were a lighter red colour (Fig 1 C). In gravid females of the same size, sonic muscles are thinner and their ventral parts have a pinkish edging (Fig. $1 \mathrm{D})$.

The swimbladder is located between the viscera and the vertebral column. It is well developed (Fig. $1 \mathrm{C}$ ) and consists of a single oval chamber with 36 to 42 pairs of arborescent appendages (Fig. 1 B, AA) in its anterior part. It is supplied by a special artery (Fig. 1.C) probably branched off directly from the aorta. The swimbladder walls are up to $1 \mathrm{~cm}$ thick as seen in figure $1 \mathrm{~B}$, in which the swimbladder is deflated.

\section{The sounds}

Meagre spawning sounds were produced during spawning periods in the Gironde estuary in dense choruses in which individual sound emissions were impossible to discriminate (Fig. 3 A). Accordingly, in our recordings, we analyzed individual sound emissions, which occurred daily before the main chorus. Meagre sounds were of two types: long and short grunts.

\section{Long grunts}

The most common calls were long grunts with durations of 598 to 2496 ms (Figs. 2 and 3). The rate of calling (12-13 long grunts per minute), as well as the call duration varied individually (Table 1).

Long grunts consisted of trains of 30 to 112 pulses. The pulse period (i.e. sonic muscle contraction rate) was very regular: mean $=20.1 \mathrm{~ms}$, S.D. $=0.9 \mathrm{~ms}(\mathrm{n}=77)$, giving a pulse rate frequency varying between 41 and $52 \mathrm{~Hz}$ (Mean $=50$, S.D. $=2, n=77$, fig. 2). Pulses consisted of about 3 cycles and varied in duration from 7.4 to $14.4 \mathrm{~ms}$ (Mean $=11 \mathrm{~ms}$, S.D. $=$ $1.6 \mathrm{~ms}, \mathrm{n}=77$ ). Their dominant frequency ranged from 336 to $444 \mathrm{~Hz}$. (Table 1). Most energy occurred in the first cycle, and the amplitude of the second cycle decayed by about half. A third cycle was barely above background. The period of each successive cycle increased suggesting a forced response rather than one dictated by the resonant frequency of the bladder.

\section{Short grunts}

Short grunts consisted of trains of 4 to 6 pulses (Fig. 4). Pulses consisted of 1 and a half to two and a half cycles and varied in duration from 4.5 to $11.7 \mathrm{~ms}$ (Mean $=7 \mathrm{~ms}$, S.D. $=$ $2 \mathrm{~ms}, \mathrm{n}=33$ ). Similarities were observed in the waveform of short grunts and long grunts. The short grunt durations varied from 69.9 to $99.2 \mathrm{~ms}$ and their periods between 594 and 5281 ms (Table 1). Although distance to the recorded fish is unknown, the somewhat shorter and weaker pulses suggest that this sound may be weaker than the long grunt. After short grunt emissions, long calls of nearby individuals ceased. 


\section{DISCUSSION}

Along with the Nile delta and the Lévrier Bay (Nouadhibou, Mauritania), the Gironde estuary is one of three main spawning sites of the meagre in the North Atlantic and the Mediterranean Sea (Quéro, 1989a, b). In the spawning site of the Gironde estuary, a large number of meagre adults aggregates during May to July. It is presumed that the function of the call is to aggregate males and females, facilitating successful mating in highly turbid water (Irigoien \& Castel, 1997; Doxaran et al., 2002; Schäfer et al., 2002). Connaughton \& Taylor (1995) indicated that in the weakfish, synchrony of the reproductive activity of male and female may be "fine tuned" by sound production only on a seasonal and/or daily scale. In the Gironde estuary, the meagre's sound productions herald the imminence of the spawning period, which generally takes place throughout June and the beginning of July (Quéro et al., 1987; Quéro \& Vayne, 1987), with a spawning peak in the first two weeks of June (Quéro \& Vayne, 1989; Quéro, 1989a). Moreover, there is a very strong link between these sounds and the meagre's seasonal fishing practice in the Gironde estuary. This very old and particular type of fishing (ear to the hull of the boat) starts in June and finishes in mid-July. This fishing method also seems to be practised in China and Japan for other sciaenid species (Takemura et al., 1978).

In this study, we have not made continuous recordings of meagre spawning sounds during a $24 \mathrm{~h}$ period. Nevertheless, the knowledge of the fishermen places the peak of meagre sound emissions late in the afternoon, in accordance with what is known concerning several other sciaenid species (Mok \& Gilmore, 1983; Holt, 2003).

Both sexes having sonic muscles (Dufossé, 1874; our personal observations at fish market), it was not possible to distinguish between male and female sounds in field conditions. Nevertheless, we observed on board the fishing boat that adult males (weighing between 6 and $20 \mathrm{~kg}$ ) continued having contractions of the sonic muscles (felt with our hands) and long grunts were heard for a few minutes after being caught. Females, which were caught less often, were not observed producing sound. In addition, hypertrophy in male sonic muscles, similar to those observed in the male weakfish Cynoscion regalis (Ono \& Poss, 1982; Connaughton \& Taylor, 1994; Connaughton et al., 1997), lead us to believe that meagre males could be the main contributors to our recorded sound emissions. However, our observations do not allow us yet to reject sound production by females which could exist as observed by Takemura et al. (1978).

The number of long grunts produced by meagre per minute remained relatively constant for a given individual for the recordings of several tens of minutes. This regularity appears very similar to that observed in weakfish, another member of the Sciaenidae spawning in the bay and in estuaries of the mid-Atlantic Bight, bodies of water also noted for their high turbidity (Connaughton \& Taylor, 1996). In both these species, the repetition rate of calls per minute does not change and these calls seem likely to serve the formation of spawning aggregations (Mok \& Gilmore, 1983; Gilmore, 2003), rallying individuals on the same spawning site. As a matter of fact, this regularity in sound emission by the meagre contrasts with the changing rate of knocking by the haddock male (Melanogrammus aeglefinus) increasing as the spawning event approaches and, in the case of haddock, considered as a mating synchronizer (Hawkins, 1993; Hawkins \& Amorim, 2000).

The recording of short grunts was rare in the field. Therefore, it is difficult to interpret the potential role of these short calls. As related in our results, these short calls resulted in stopping a regular emission of long grunts in their immediate vicinity. Several authors (Connaughton \& Taylor, 1996; Connaughton et al., 2002) indicated that drumming ceased when the male weakfish (Cynoscion regalis) left the bottom in pursuit of female, and no drumming was heard during pursuit or gamete release. For an other sciaenid species: red 
drum (Sciaenops ocellata), no sounds were heard when males were actively nudging female or during gamete release (Guest \& Lasswell, 1978). Because meagre short calls correlated with the cessation of drumming, we suggest they were emitted by a female meeting a male to involve a courtship with it, or by a male starting a pursuit of a female.

Connaughton et al. (2002, 2003) demonstrated a close relationship between water temperature, fish size and dominant frequency in weakfish and Atlantic croaker. Dominant frequency increases with increasing water temperature and decreases with increasing fish size. We could presume it is the same for meagre whose male adult weight varies between 3 and more than $20 \mathrm{~kg}$, and for which temperatures in the Gironde estuary can vary between $16^{\circ} \mathrm{C}$ at the beginning of June and over $21^{\circ} \mathrm{C}$ in July. In addition, difference in the dominant frequency can also be a sexual characteristic. Takemura et al. (1978) observed that dominant frequency of males was higher than that of females.

Drumming sounds produced by members of Sciaenidae are examples of pulse sounds. In this case, a single pulse corresponds to a unit of muscle activity (Tower, 1908). Each acoustic pulse is induced by a simultaneous single sonic muscle twitch, which in turn is preceded by a single nerve volley (Skoglund, 1961; Cohen \& Winn, 1967; Connaughton et al., 2000). The acoustic waveform of meagre pulses decays rapidly (Fig. 2 C). The sound spectrum of an individual pulse contains energy with a wide bandwidth (Fig. 3 E). These characteristics are typical of a low-Q, broadly tuned resonator (Bradbury \& Vehrenkamp, 1998) responding to contractions of the sonic muscle rather than the natural frequency of the swimbladder (Fine et al., 2001; Connaughton et al., 2002). As result, in meagre, each muscle twitch produces multiple swimbladder vibrations causing the radiated sound with the cycle of each individual pulse (cycle with the greatest amplitude) giving the dominant frequency of the sound (Fig. 3 E). This mechanism of sound generation appears identical to the previous description in weakfish by Connaughton et al. (2002) and modeled by Sprague (2000) as the single sonic muscle twitch model (SSMT model). Nevertheless, the meagre spawning sounds are different from typical sciaenid sounds because pulses are so close together (pulse period = $20 \mathrm{~ms}$ ) that they are heard as a unit of pulses (long grunt) rather than a train of individual pulses. This characteristic gives a tonal nature to the long grunt sound emissions contrasting with the pulsed sound emitted by the majority of other sciaenid species (Fish \& Mowbray, 1970), excepted the two species studied by Takemura et al. (1978) : Nibea albiflora and Argyrosomus argentatus.

I (JPL) would like to thank J.P. Royer for his valuable local knowledge and guidance in fish sound location and the referees for their very positive suggestions and remarks. We wish to thank J. Jenkinson for improving the language. 


\section{References}

Aubin, T. (1994). Syntana : a software for the synthesis analysis of animal sounds, Bioacoustics 6, 80-81.

Bradbury, J.W. \& Vehrenkamp S.L. (1998). Principles of Animal Communication. Sunderland: Sinauer Associates.

Chao, L. N. (1986). Sciaenidae. In: Fishes of the eastern Atlantic and Mediterranean = Poissons de l'Atlantique du nord-est et de la Méditerranée (Whitehead, P. J. P., Bauchot, M.-L., Hureau, J. C. \& Tortonese, E., eds), pp. 865-874. Paris: Unesco.

Cohen, M.J. \& Winn, H.E. (1967). Electrophysiological observations on hearing and sound production in the fish, Porichthys notatus. Journal of Experimental Zoology 165, 355-370.

Connaughton, M. A. \& Taylor M. H. (1994). Seasonal cycles in the sonic muscles of the weakfish, Cynoscion regalis. Fishery Bulletin 92, 697-703.

Connaughton, M. A. \& Taylor M. H. (1995). Seasonal and daily cycles in sound production associated with spawning in the weakfish, Cynoscion regalis. Environmental Biology of Fishes 42, 233-240.

Connaughton, M. A. \& Taylor M. H. (1996). Drumming, courtship, and spawning behavior in captive weakfish, Cynoscion regalis. Copeia 1996, 195-199.

Connaughton, M. A., Fine, M. L. \& Taylor M. H. (1997). The effects of seasonal hypertrophy and atrophy on fiber morphology, metabolic substrate concentration and sound characteristics of the weakfish sonic muscle. The Journal of Experimental Biology 200, 2449-2457.

Connaughton, M. A., Taylor M. H. \& Fine, M. L. (2000). Effects of fish size and temperature on weakfish disturbance calls: implications for the mechanism of sound generation. The Journal of Experimental Biology 203, 1503-1512.

Connaughton, M. A., Fine, M. L. \& Taylor M. H. (2002). Review. Weakfish sonic muscle: influence of size, temperature and season. The Journal of Experimental Biology 205, 2183-2188.

Connaughton, M. A.,Lunn, M. L., Fine, M. L. \& Taylor M. H. (2003). Characterization of sounds and their use in two sciaenid species: weakfish and Atlantic croaker. In Listening to Fish: Proceedings of the International Workshop on the Applications of Passive Acoustics to Fisheries, April 8-10, 2002 (Rountree, R.A., Goudey, C. \& Hawkins, T. eds).pp. 1-4. MIT Sea Grant Technical Report, Dedham, MA.

Doxaran, D., Froidefond, J-M., Lavender, S. \& Castaing, P. (2002). Spectral signature of highly turbid waters. Application with SPOT data to quantify suspended particulate matter concentrations. Remote Sensing of Environment 81, 149-161.

Dufossé, M. (1874). Recherches sur les bruits et les sons expressifs que font entendre les poissons d'Europe et sur les organes producteurs de ces phénomènes acoustiques ainsi que sur les appareils de l'audition de plusieurs de ces animaux. Annales des Sciences Naturelles 19, 1-134.

Duhamel de Monceau, H. L. (1769-1789). Traité général des pesches et Histoire des poissons qu'elles fournissent tant pour la subsistance des hommes que pour plusieurs autres usages qui ont rapport aux Arts et au Commerce. Paris, 3 (1777), 136-139.

Fine, M.L., Malloy, K.L., King, C.B., Mitchell, S.L. \& Cameron, T.M. (2001). Movement and sound generation by the toadfish swimbladder. Journal of Comparative Physiology A 187 : 371-379.

Fish, M. P. \& Mowbray, W. H. (1970). Sounds of western North Atlantic fishes. Baltimore: Johns Hopkins Press.

Gilmore, R.G. (2003). Passive acoustic transects: mating calls and spawning ecology in East Florida Sciaenids. In Listening to Fish: Proceedings of the International Workshop 
on the Applications of Passive Acoustics to Fisheries, April 8-10, 2002 (Rountree, R.A., Goudey, C. \& Hawkins, T. eds).pp. 1-10. MIT Sea Grant Technical Report, Dedham, MA.

Guest, W. C. \& Lasswell, J. L. (1978). A note on courtship behavior and sound production of red drum. Copeia 1978, 337-338.

Hawkins, A. D. (1993). Underwater sound and fish behaviour. In Behaviour of Teleost Fishes (Pitcher, T.J., ed.) pp. 129-170.London: Chapman \& Hall.

Hawkins, A. D. \& Amorim, M. C. P. (2000). Spawning sounds of the male haddock, Melanogrammus aeglefinus. Environmental Biology of Fishes 59, 29-41.

Hill, G. L., Fine, M. L. \& Musick, J. A. (1987). Ontogeny of the sexually dimorphic sonic muscle in three sciaenid species. Copeia 1987, 708-713.

Holt, S. A. (2003). Using a towed array to survey red drum spawning sites in the Gulf of Mexico. In Listening to Fish: Proceedings of the International Workshop on the Applications of Passive Acoustics to Fisheries, April 8-10, 2002 (Rountree, R.A., Goudey, C. \& Hawkins, T. eds).pp. 1-5. MIT Sea Grant Technical Report, Dedham, MA.

Irigoien, X. \& Castel J. (1997). Light limitation and distribution of chlorophyll pigments in a highly turbid estuary: the Gironde (SW France). Estuarine, Coastal and Shelf Science 44, 507-517.

Lengagne, T., Aubin, T., Jouventin P.\& Lauga, J. (2000) Perceptual salience of individually distinctive features in the calls of adult king penguins. The Journal of the Acoustical Society of America 107, 508-516.

Luczkovich, J. J., Sprague, M. W., Johnson, S. E. \& Pullinger, R. C. (1999). Delimiting spawning areas of weakfish, Cynoscion regalis (Family Sciaenidae) in Pamlico Sound, North Carolina using passive hydroacoustic surveys. Bioacoustics 10, 143160.

Mok, H. K. \& Gilmore, R. G. (1983). Analysis of sound production in estuarine aggregations of Pogonias cromis, Bairdiella chrysoura, and Cynoscion nebulosus (Sciaenidae). Bulletin Institute of Zoology, Academia Sinica 22, 157-186.

Ono, R. D. \& Poss, S. G. (1982). Structure and innervation of the swim bladder musculature in the weakfish, Cynoscion regalis (Teleostei: Sciaenidae). Canadian Journal of Zoology 60, 1955-1967.

Quéro, J. C. (1989a). Sur la piste des maigres Argyrosomus regius (Pisces, Sciaenidae) du Golfe de Gascogne et de Mauritanie. Océanis 15, 161-170.

Quéro, J. C. (1989b). Le maigre, Argyrosomus regius (Asso) (Pisces, Sciaenidae) en Méditerranée occidentale. Bulletin de la Société zoologique de France 14, 81-89.

Quéro, J. C. \& Vayne, J. J. (1987). Le maigre, Argyrosomus regius (Asso, 1801) (Pisces, Perciformes, Sciaenidae) du Golfe de Gascogne et des eaux plus septentrionales. Revue des Travaux de l'Institut des Pêches maritimes 49, 35-66.

Quéro, J. C., Fuchs, L. \& Vayne, J. J. (1987). Quinze années de pêche à la ligne (1950-1964) dans la Seudre et sur la côte Sauvage. Annales de la Société des Sciences naturelles de la Charente-maritime 7 (5), 647-664.

Quéro, J. C. \& Vayne, J. J. (1989). Parlons maigre. Annales de la Société des Sciences naturelles de la Charente-maritime 7 (7), 869-885.

Schäfer, J., Blanc, G., Lapaquellerie, Y., Maillet, N., Maneux, E. \& Etcheber, H. (2002). Tenyear observation of the Gironde tributary fluvial system: fluxes of suspended matter, particulate organic carbon and cadmium. Marine Chemistry 79, 229-242.

Skoglund, C.R. (1961). Functional analysis of swim-bladder muscles engaged in sound production of the toadfish. The Journal of Biophysical and Biochemical Cytology 10, 187-200. 
Sprague, M. W. (2000). The single sonic muscle twitch model for the sound-production mechanism in the weakfish, Cynoscion regalis. The Journal of the Acoustical Society of America 108, 2430-2437.

Takemura, A., Takita, T. \& Mizue, K. (1978). Studies on the underwater sound - VII. Underwater calls of the Japanese marine drum fishes (Sciaenidae). Bulletin of the Japanese Society of Scientific Fisheries 44, 121-125.

Tower, R.W. (1908). The production of sound in the drumfishes, the sea-robin and the toadfish. Annals of the New York Academy of Sciences 18, 149-180. 
Table 1 . The physical characteristics of meagre sounds.

\begin{tabular}{|c|c|c|c|c|c|c|}
\hline $\begin{array}{l}\mathrm{N}^{\circ} \text { of fish } \\
\text { Date }\end{array}$ & Type of sound & Statistic & $\begin{array}{c}\text { Call } \\
\text { duration } \\
(\mathrm{ms})\end{array}$ & $\begin{array}{l}\text { Call period } \\
\text { (ms) }\end{array}$ & $\begin{array}{l}\mathrm{N}^{\circ} \text { of } \\
\text { pulses }\end{array}$ & $\begin{array}{c}\text { Dominant } \\
\text { frequency } \\
(\mathrm{Hz})\end{array}$ \\
\hline $\begin{array}{l}1 \\
11 / 06 / 03\end{array}$ & $\begin{array}{l}\text { Long grunts } \\
N=10\end{array}$ & $\begin{array}{l}\text { Mean } \\
\text { S.D. } \\
\text { Min } \\
\text { Max }\end{array}$ & $\begin{array}{r}2170 \\
178 \\
1832 \\
2490.6\end{array}$ & $\begin{array}{r}4409 \\
450 \\
3873 \\
5471\end{array}$ & $\begin{array}{r}108 \\
3 \\
105 \\
112\end{array}$ & $\begin{array}{r}389 \\
27\end{array}$ \\
\hline $\begin{array}{l}2 \\
13 / 06 / 03\end{array}$ & $N=3$ & $\begin{array}{l}\text { Mean } \\
\text { S.D. } \\
\text { Min } \\
\text { Max }\end{array}$ & $\begin{array}{r}1074 \\
92 \\
953 \\
1176\end{array}$ & $\begin{array}{l}4587 \\
5929\end{array}$ & $\begin{array}{r}59 \\
4 \\
53 \\
64\end{array}$ & $\begin{array}{r}395 \\
26\end{array}$ \\
\hline $\begin{array}{l}3 \\
13 / 06 / 03\end{array}$ & $N=8$ & $\begin{array}{l}\text { Mean } \\
\text { S.D. } \\
\text { Min } \\
\text { Max } \\
\end{array}$ & $\begin{array}{r}1430 \\
139 \\
1245 \\
1625 \\
\end{array}$ & $\begin{array}{r}2837 \\
321 \\
2371 \\
3279 \\
\end{array}$ & & $\begin{array}{r}420 \\
13\end{array}$ \\
\hline $\begin{array}{l}4 \\
20 / 06 / 03\end{array}$ & $N=12$ & $\begin{array}{l}\text { Mean } \\
\text { S.D. } \\
\text { Min } \\
\text { Max }\end{array}$ & $\begin{array}{r}1043 \\
129 \\
836 \\
1232\end{array}$ & $\begin{array}{r}3029 \\
373 \\
2613 \\
3734\end{array}$ & $\begin{array}{r}58 \\
7 \\
46 \\
68\end{array}$ & $\begin{array}{r}410 \\
26\end{array}$ \\
\hline $\begin{array}{l}5 \\
20 / 06 / 03\end{array}$ & $N=9$ & $\begin{array}{l}\text { Mean } \\
\text { S.D. } \\
\text { Min } \\
\text { Max } \\
\end{array}$ & $\begin{array}{r}1075 \\
217 \\
598 \\
1283 \\
\end{array}$ & $\begin{array}{r}2589 \\
360 \\
1909 \\
2980 \\
\end{array}$ & $\begin{array}{l}60 \\
13 \\
33 \\
71 \\
\end{array}$ & $\begin{array}{r}444 \\
34\end{array}$ \\
\hline $\begin{array}{l}6 \\
25 / 06 / 04\end{array}$ & $N=9$ & $\begin{array}{l}\text { Mean } \\
\text { S.D. } \\
\text { Min } \\
\text { Max }\end{array}$ & $\begin{array}{r}1432 \\
191 \\
1066 \\
1696 \\
\end{array}$ & $\begin{array}{r}3728 \\
594 \\
3067 \\
4668 \\
\end{array}$ & $\begin{array}{l}72 \\
10 \\
54 \\
86\end{array}$ & $\begin{array}{r}366 \\
25\end{array}$ \\
\hline $\begin{array}{l}7 \\
25 / 06 / 04\end{array}$ & $N=18$ & $\begin{array}{l}\text { Mean } \\
\text { S.D. } \\
\text { Min } \\
\text { Max } \\
\end{array}$ & $\begin{array}{r}1533 \\
303 \\
637 \\
1954 \\
\end{array}$ & $\begin{array}{l}3725 \\
1034 \\
2209 \\
6629 \\
\end{array}$ & $\begin{array}{l}76 \\
16 \\
30 \\
97\end{array}$ & $\begin{array}{r}363 \\
17\end{array}$ \\
\hline $\begin{array}{l}8 \\
25 / 06 / 04\end{array}$ & $N=7$ & $\begin{array}{l}\text { Mean } \\
\text { S.D. } \\
\text { Min } \\
\text { Max }\end{array}$ & $\begin{array}{r}1893 \\
141 \\
1705 \\
2081 \\
\end{array}$ & $\begin{array}{r}4472 \\
653 \\
3921 \\
5379 \\
\end{array}$ & $\begin{array}{r}92 \\
7 \\
83 \\
101\end{array}$ & $\begin{array}{r}336 \\
25\end{array}$ \\
\hline $\begin{array}{l}9 \\
25 / 06 / 04\end{array}$ & $\begin{array}{l}\text { Short grunts } \\
N=10\end{array}$ & $\begin{array}{l}\text { Mean } \\
\text { S.D. } \\
\text { Min } \\
\text { Max }\end{array}$ & $\begin{array}{r}80 \\
9 \\
70 \\
99\end{array}$ & $\begin{array}{r}1267 \\
1630 \\
594 \\
5281\end{array}$ & $\begin{array}{l}5 \\
1 \\
4 \\
6\end{array}$ & $\begin{array}{r}383 \\
34\end{array}$ \\
\hline
\end{tabular}




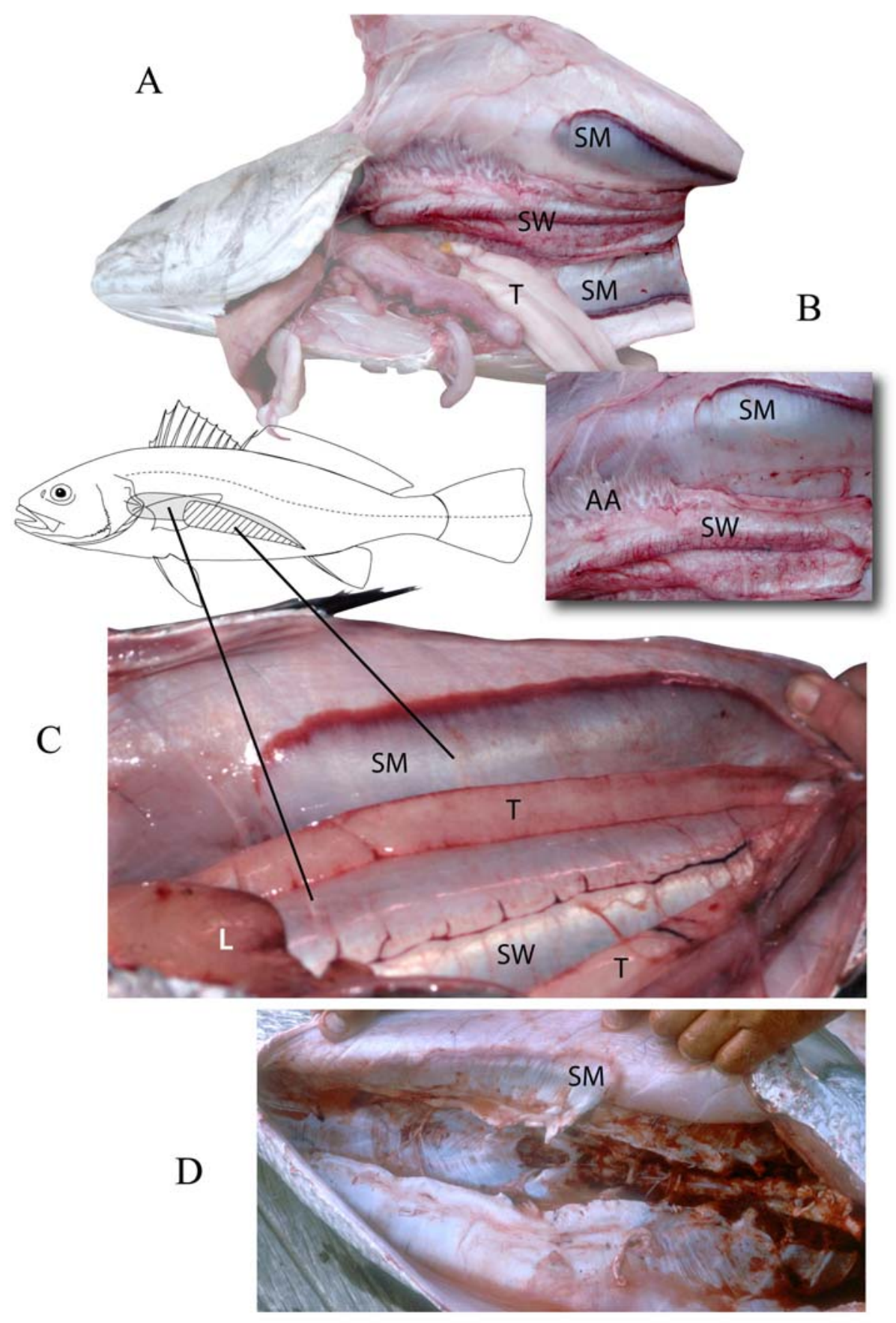

Figure 1. Illustration of location and sexual dimorphism of sonic muscles in the meagre Argyrosomus regius : (A) photograph of body cavity and raised left body wall of a spermproducing male (6 kg, caught on 2003-06-14); (B) enlargement of the same picture showing anterior part of a deflated swimbladder (SW) with its arborescent appendages (AA) and the left hypertrophied sonic muscle (SM); (C) photograph of body cavity of a non spermproducing male (17 kg, caught on 2004-03-19) showing colour change of the sonic muscle and its extent on the left body wall: $\mathrm{T}=$ testicle, $\mathrm{L}=$ liver; (D) photograph of right body wall of a pre-spawning female (13 kg, caught on 2005-06-22) showing the less developed and pink coloured of the sonic muscle. In panels A, B and C, anterior is to the left; in panel D, anterior is to the right side of the image. 

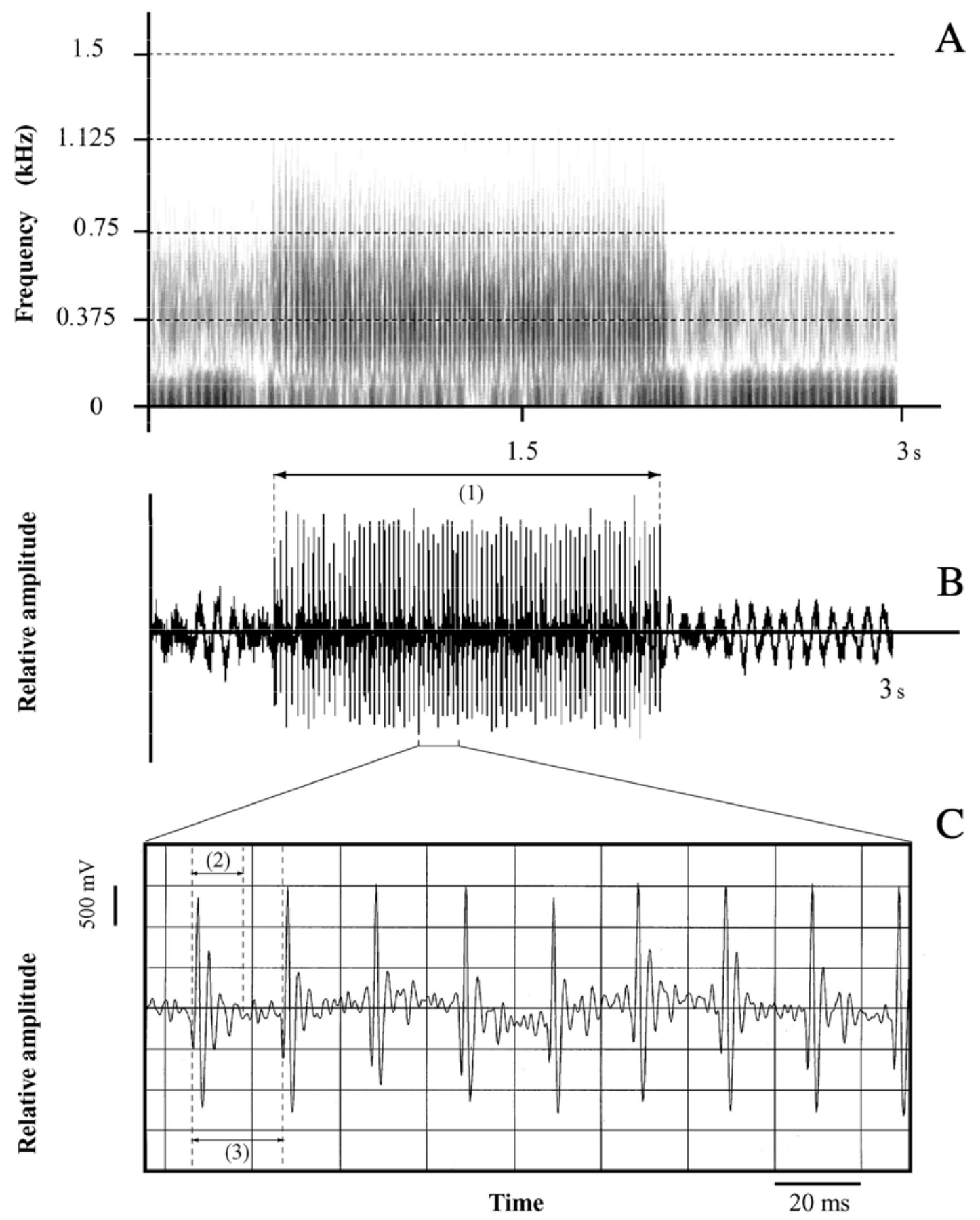

Figure 2. Sonogram (A) and oscillograms (B) and (C) of a long grunt produced by meagre in field conditions. Characteristics measured in the signal: (1) train duration, (2) pulse length, (3) pulse period. 

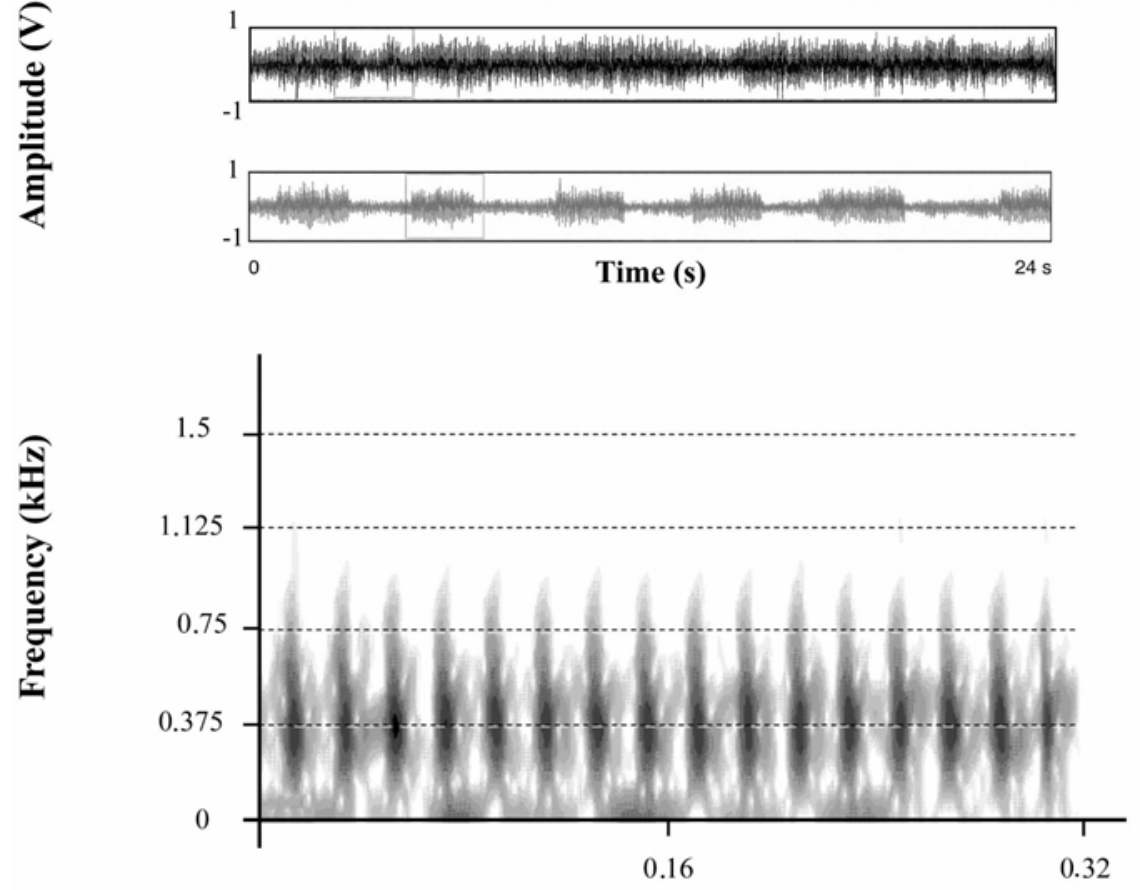

$\mathrm{C}$

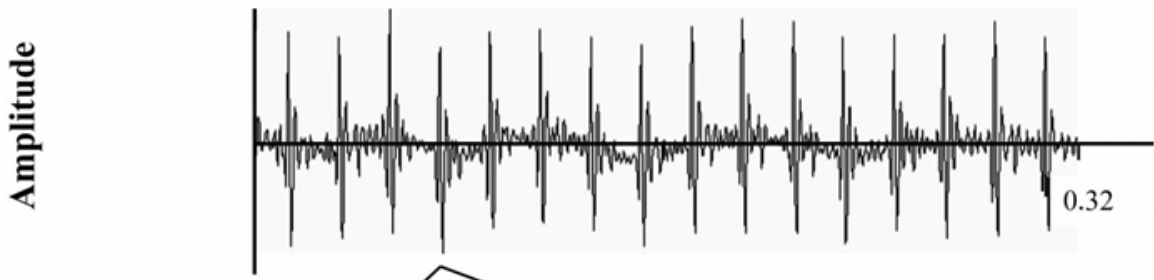

$\mathrm{D}$

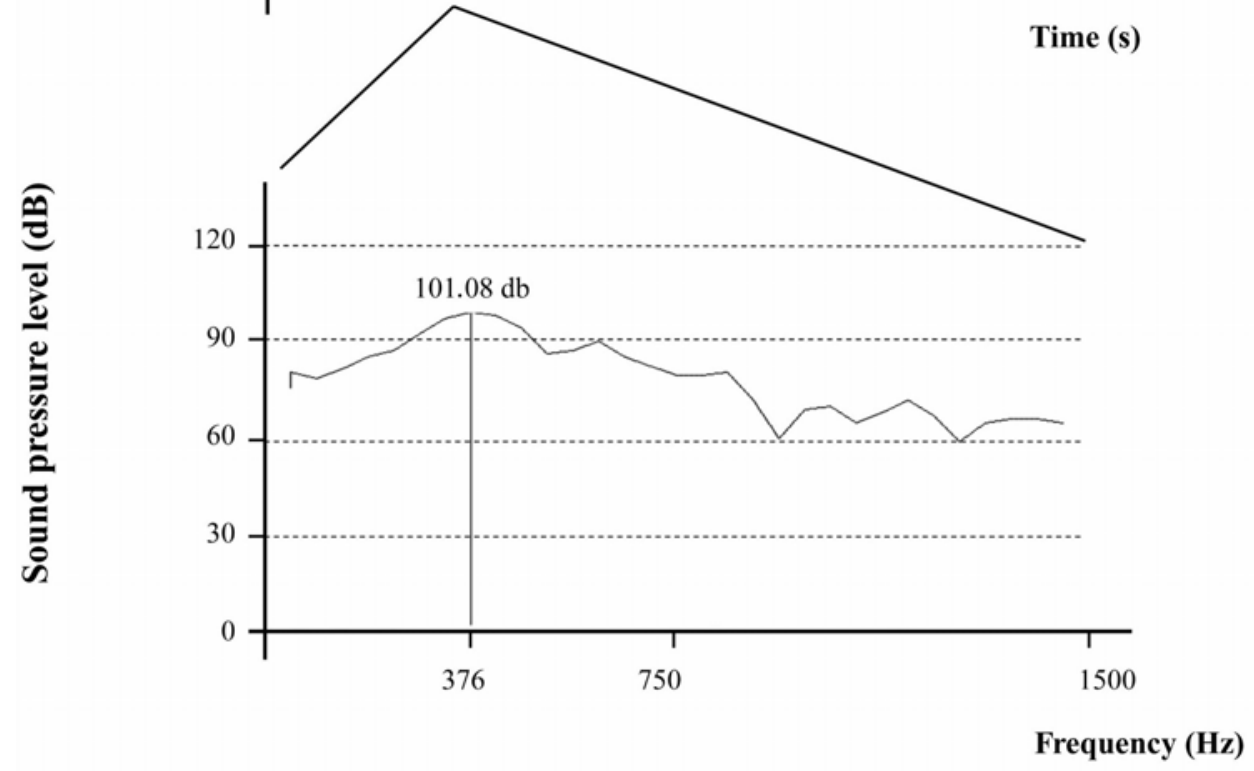

Figure 3. Oscillograms of chorus (A) and individual long grunts (B) produced by meagre during spawning period in the Gironde estuary. Sonogram (C) and oscillogram (D) of a typical meagre long grunt consisting of a series of individual sound pulses. Spectrum (E) of one of these pulses demonstrating a dominant frequency at $376 \mathrm{~Hz}$. 

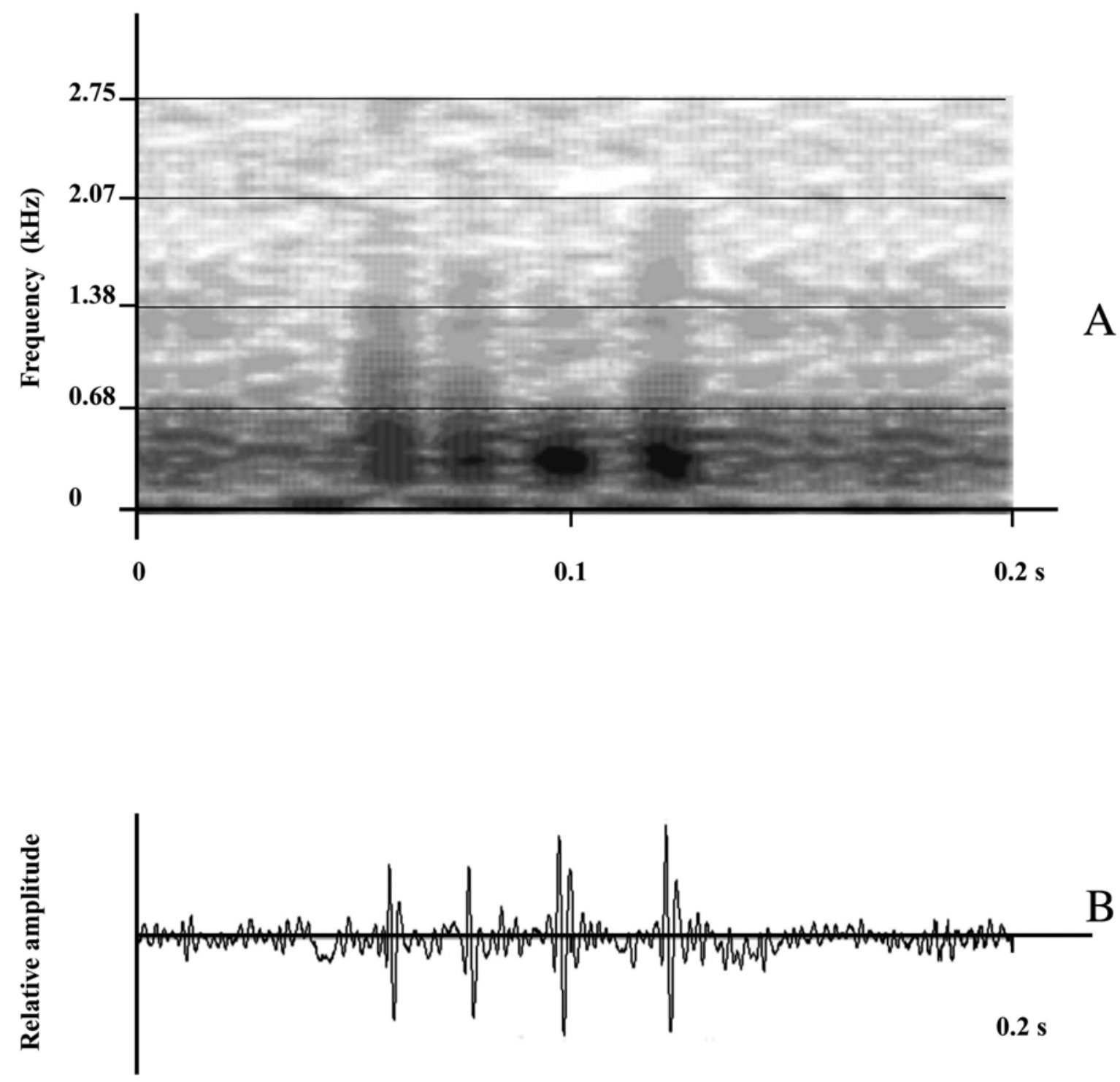

Time

Figure 4. Sonogram (A) and oscillogram (B) of one meagre short grunt (heard much less often than long grunts) recorded during spawning period under field conditions. 